\title{
Update: Intravenous immune globulin in children
}

$\mathrm{T}$ he INFECtious Diseases ANd IMmunization CommitTeE of the Canadian Paediatric Society made recommendations on the use of intravenous immune globulin (IgIV) in children in 1992 (1). Certain conditions were listed in which the efficacy of IgIV has been established including replacement therapy in antibody deficiency states, immune thrombocytopenic purpura and Kawasaki disease. Other conditions were listed in which the efficacy of IgIV was not yet established. Based on the quality of available data, these latter conditions were further divided into those in which IgIV would probably or possibly prove to be efficacious. The committee resolved to update the statement as further studies on the use of IgIV became available.

In the three years since publication of the guidelines, several studies of the efficacy of IgIV therapy have been reported. These studies have led the committee to modify its recommendations. Well controlled studies were published evaluating the use of IgIV in adults with Guillain-Barré syndrome and other polyneuropathies $(2,3)$. In patients with Guillain-Barré syndrome, recovery was improved and hastened by IgIV therapy, and there were fewer complications and decreased need for artificial ventilation. Another well designed study in adults showed a significant benefit of IgIV for treatment of refractory dermatomyositis (4).

A large multicentred, placebo controlled, double-blind study of IgIV therapy in children with symptomatic human immunodeficiency virus (HIV) infection demonstrated that prophylactic use of IgIV increased the time free from serious bacterial infection and minor bacterial and viral infections $(5,6)$. The study was limited to children under 13 years of age without hemophilia; most were under five years of age and had acquired HIV infection by vertical transmission from infected mothers. The protective effect of IgIV was limited to

All material presented in Pediatric Infectious Disease Notes has been reviewed and approved by the chairperson, Canadian Pediatric Society Board representative and members of the Canadian Pediatric Society Committee on Infectious Diseases and Immunization

Correspondence and reprints: Infectious Diseases and Immunization Committee, Canadian Paediatric Society, 401 Smyth Rd, Ottawa, ON K1H 8L1. Telephone (613) 737-2728, Fax (613) 737-2794 children who entered the study with CD4 counts of $0.2 \times 10^{9} / \mathrm{L}$ or more; there were too few children with lower CD4 counts to show any beneficial effect, or there may be no effect in this group. Irrespective of CD4 counts, there was no significant effect of IgIV therapy on overall mortality. More recently, another large multicentred, randomized, placebo controlled, doubleblind study demonstrated a beneficial effect of prophylactic IgIV therapy only in HIV-infected children who were not receiving trimethoprim-sulphamethoxazole therapy (7). The authors hypothesized that lower rates of zidovudine use and trimethoprim-sulphamethoxazole prophylaxis for Pneumocystis carinii pneumonia in the earlier study may have contributed to the differences in the findings.

Use of IgIV prophylactically to prevent infections in low birth weight neonates remains controversial. The results of four placebo controlled, double-blind studies have recently been reported. One study demonstrated a decreased risk of nosocomial infection in premature infants with birth weights between 500 and $1750 \mathrm{~g}$, although morbidity and mortality were not affected (8). Two other smaller studies failed to show a beneficial effect $(9,10)$. The most recently reported study, a large multicentred placebo controlled study, also showed no benefit of IgIV in preventing nosocomial infections in infants weighing between 500 and $1500 \mathrm{~g}$ (11). This study noted a lower incidence in the rate of nosocomial infections in both treated and untreated participants than reported in the earlier study by Baker et al (8). Of particular concern is the higher association of necrotizing enterocolitis in neonates infused with IgIV reported in two of the studies $(9,11)$.

The use of IgIV in pediatric bone marrow transplant centres is becoming routine (12), although data supporting its use are scarce. Most studies have demonstrated a beneficial effect of IgIV in the prevention of cytomegalovirus (CMV) infections in CMV-negative recipients of bone marrow transplants; a recent meta-analysis supported these conclusions (13). However, another study failed to show any incremental benefit of IgIV prophylaxis compared with use of CMV seronegative blood products in bone marrow transplant patients, although the power of the study was small (14). Other benefits were suggested in the IgIV treated patients including a decrease in Gram-negative septicemia and local infections (15), non-CMV viral infections and overall deaths related to infection (14) and non-CMV interstitial pneumonia (13). A decrease in graft- 
versus-host disease was shown in IgIV treated patients (14), although this benefit was only observed in patients older than 20 years (15).

The increased use of IgIV has heightened our recognition of the range of associated adverse events, several of which have been reported since the original committee recommendations (1). The incidence of aseptic meningitis following IgIV infusion may be higher than previously thought, particularly with infusion at very high doses $(2 \mathrm{~g} / \mathrm{kg})(16,17)$. Non-A, non-B hepatitis had not previously been reported in products licensed in North America; however, cases of hepatitis $C$ have now been associated with IgIV from one manufacturer in the United States during a brief period in 1993 (18). Additional methods of viral inactivation used by other manufacturers should reduce this risk (19); however, because of the risk of transmission of as yet unknown blood-borne infections, IgIV should be used only if there is a clear indication. Furthermore, our understanding is increasing of the potential effect of high doses of IgIV on the response to live virus vaccines, particularly measles. In the original committee recommendations, a delay of measles immunization for three months after IgIV infusion was suggested. More recent recommendations suggest a delay of from three to 11 months depending on the product and dose of immune globulin given $(20,21)$.

Based on these additional data, the Infectious Diseases and Immunization Committee believes that there is sufficient information to modify the previously published guidelines (1). The committee now considers IgIV therapy of probable (rather than possible) efficacy for treatment of Guillain-Barré syndrome, refractory dermatomyositis and for prophylaxis for CMV infections after bone marrow transplantation. In contrast, recent data are less supportive of routine use of IgIV for prophylaxis against nosocomial infections in low birth weight neonates; therefore, the committee now considers this use of possible efficacy (rather than probable efficacy). Because of conflicting data, the committee continues to consider as probable efficacy the use of IgIV in children with HIV infection and in children who receive a bone marrow or organ transplant.

\section{REFERENCES}

1. Infectious Diseases and Immunization Committee, Canadian Paediatric Society. Intravenous immune globulin use in children. Can Med Assoc J 1992;146:121-4.

2. van der Meché FGA, Schmitz PIM, The Dutch Guillain-Barré Study Group. A randomized trial comparing intravenous immune globulin and plasma exchange in Guillain-Barré syndrome. N Engl J Med 1992;326:1123-9.

3. van Doorn PA, Brand A, Strengers PFW, Meulstee J, Vermeulen $M$. High-dose intravenous immunoglobulin treatment in chronic inflammatory demyelinating polyneuropathy: a double-blind, placebo-controlled, crossover study. Neurology 1990;40:209-12.

4. Dalakas MC, Illa I, Dambrosia JM, et al. A controlled trial of high-dose intravenous immune globulin infusions as treatment for dermatomyositis. N Engl J Med 1993;329:1993-2000.

5. The National Institute of Child Health and Human Development Intravenous Immunoglobulin Study Group. Intravenous immune globulin for the prevention of bacterial infections in children with symptomatic human immunodeficiency virus infection. $\mathrm{N}$ Engl J Med 1991;325:73-80.

6. Mofenson LM, Moye J Jr, Bethel J, et al. Prophylactic intravenous immunoglobulin in HIV-infected children with $\mathrm{CD} 4^{+}$ counts of $0.20 \times 10^{9} / L$ or more. JAMA 1992;268:483-8.

7. Spector SA, Gelber RD, McGrath N, et al. A controlled trial of intravenous immune globulin for the prevention of serious bacterial infections in children receiving zidovudine for advanced human immunodeficiency virus infection. N Engl J Med 1994;331:1181-7.

8. Baker CJ, Melish ME, Hall RT, et al. Intravenous immune globulin for the prevention of nosocomial infection in low-birth-weight neonates. N Engl J Med 1992;327:213-9.

9. Magny JF, Bremard-Oury C, Brault D, et al. Intravenous immunoglobulin therapy for prevention of infection in high-risk premature infants: report of a multicenter, double-blind study. Pediatrics 1991;88:437-43.

10. Kinney J, Mundorf L, Gleason C. Efficacy and pharmacokinetics of intravenous immune globulin administration to high-risk neonates. Am J Dis Child 1991;145:1233-8.

11. Fanaroff $A A$, Korones $S B$, Wright $L L$, et al. A controlled trial of intravenous immune globulin to reduce nosocomial infections in very low-birth-weight infants.

N Engl J Med 1994;330:1107-13.

12. Casper JT, Sedmark G, Harris RE, et al. Intravenous immunoglobulin: use in pediatric bone marrow transplantation. Semin Hematol 1992;29(Suppl 2):100-5.

13. Bass EB, Powe NR, Goodman SN, et al. Efficacy of immune globulin in preventing complications of bone marrow transplantation: a meta-analysis. Bone Marrow Transplant 1993;12:273-82.

14. Winston DJ, Ho WG, Bartoni K, Champlin RE. Intravenous immunoglobulin and CMV-seronegative blood products for prevention of CMV infection and disease in bone marrow transplant recipients. Bone Marrow Transplant 1993;12:283-8.

15. Sullivan KM, Kopecky KJ, Jocom J, et al. Immunomodulatory and antimicrobial efficacy of intravenous immunoglobulin in bone marrow transplantation. N Engl J Med 1990;323:705-12.

16. Sekul EA, Cupler EJ, Dalakas MC. Aseptic meningitis associated with high-dose intravenous immunoglobulin therapy: frequency and risk factors. Ann Intern Med 1994;121:259-62.

17. Scribner CL, Kapit RM, Phillips ET, Rickles NM. Aseptic meningitis and intravenous immunoglobulin therapy. Ann Intern Med 1994;121:305-6.

18. Schneider L, Geha R. Outbreak of hepatitis $C$ associated with intravenous immunoglobulin administration - United States, October 1993-June 1994. MMWR 1994;43;505-9.

19. Edwards CA, Piet NPJ, Chin S, Horowitz B. Tri(n butyl) phosphate detergent treatment of licensed therapeutic and experimental blood derivatives. Vox Sang 1987;52:53-9.

20. Committee on Infectious Diseases. Recommended timing of routine measles immunization for children who have recently received immune globulin preparations. Pediatrics 1994;93:682-5.

21. National Advisory Committee on Immunization. Canadian Immunization Guide, 4th edn. Ottawa: Health Canada, 1993:14-5.

\section{Canadian Paediatric Society Infectious Diseases and Immunization Committee}

\begin{abstract}
Members: Michael Hall (director responsible), St John's, Newfoundland; Noni E MacDonald (chair), Department of Pediatrics, Children's Hospital of Eastern Ontario, Ottawa, Ontario; Scott A Halperin (principal author), Izaak Walton Killam Children's Hospital, Halifax, Nova Scotia; William Albritton, Provincial Laboratory of Public Health, Edmonton, Alberta; François Boucher, Département de pédiatrie, Centre hospitalier de l'Université Laval, Ste-Foy, Québec; Gilles Delage, Adjoint médical, Service de transfusion de sang de la Croix-Rouge canadienne, Centre de Montréal, Montréal, Québec; Elizabeth Ford-Jones, Division of Infectious Disease, The Hospital for Sick Children, Toronto, Ontario; Susan King, Division of Infectious Disease,
\end{abstract}


The Hospital for Sick Children, Toronto, Ontario; David P Speert, Research Centre, Vancouver, British Columbia.

Ex-Officio Members: Frank R Friesen (Chair, Committee on Committees), Manitoba Clinic, Winnipeg, Manitoba.

Consultants: Ronald Gold, Division of Infectious Disease, The Hospital for Sick Children, Toronto, Ontario; Victor Marchessault, Department of Pediatrics, Children's Hospital of Eastern Ontario, Ottawa, Ontario.
Epidemiology, Public Health Branch, Toronto, Ontario; American Academy of Pediatrics, Larry Pickering, Eastern Virginia Medical School, Children's Hospital of the King's Daughters, Norfolk, Virginia; Centre for Vaccine Evaluation, David Scheifele, Division of Infectious Diseases, Research Centre, BC's Children's Hospital, Vancouver, British Columbia; Epidemiology, John Waters, Alberta Health, Communicable Disease Control, Edmonton, Alberta 


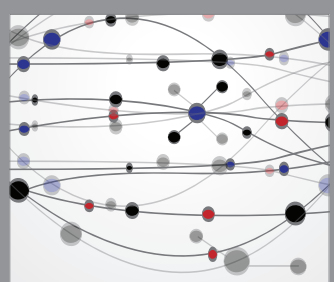

The Scientific World Journal
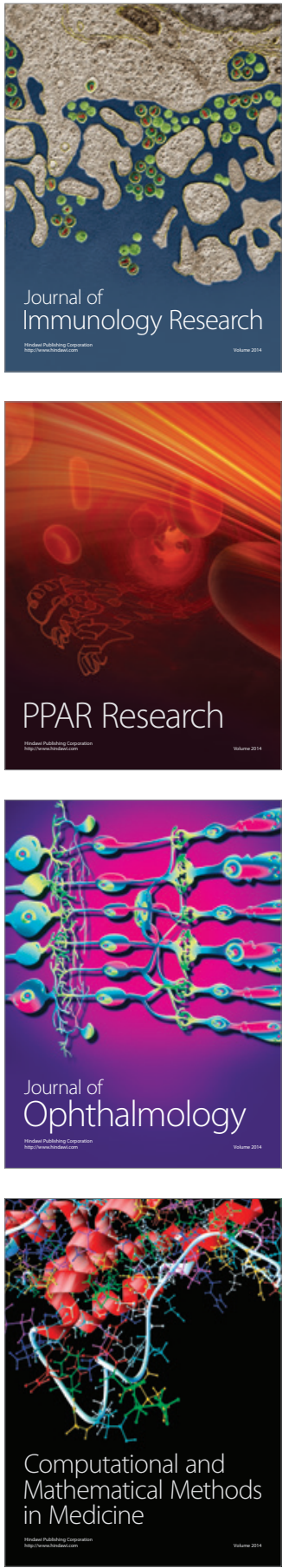

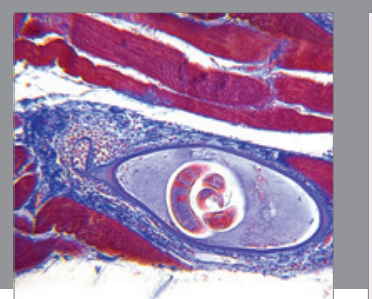

Gastroenterology Research and Practice

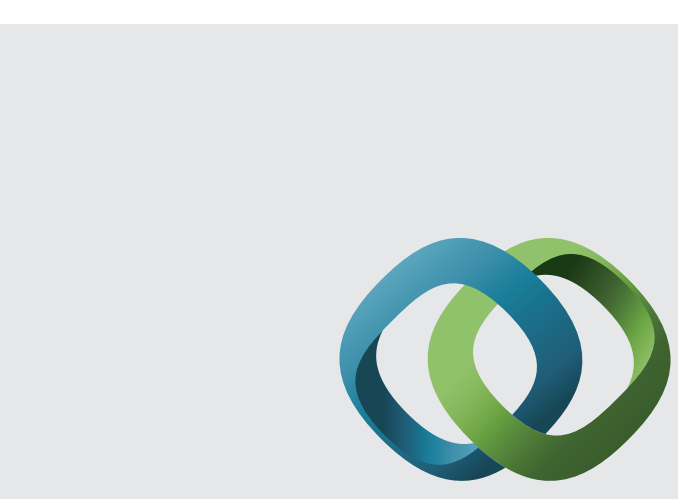

\section{Hindawi}

Submit your manuscripts at

http://www.hindawi.com
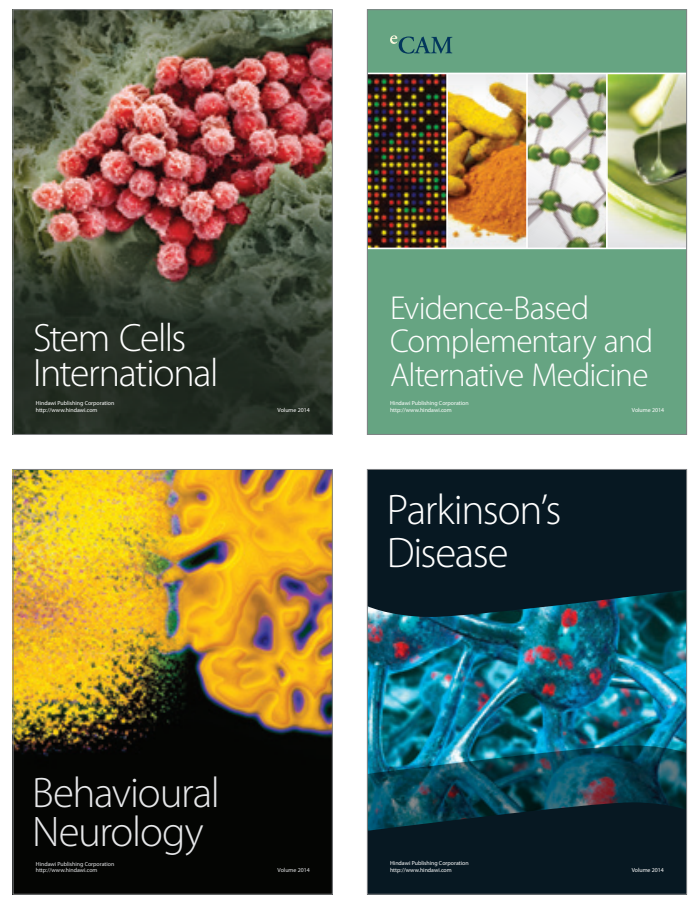
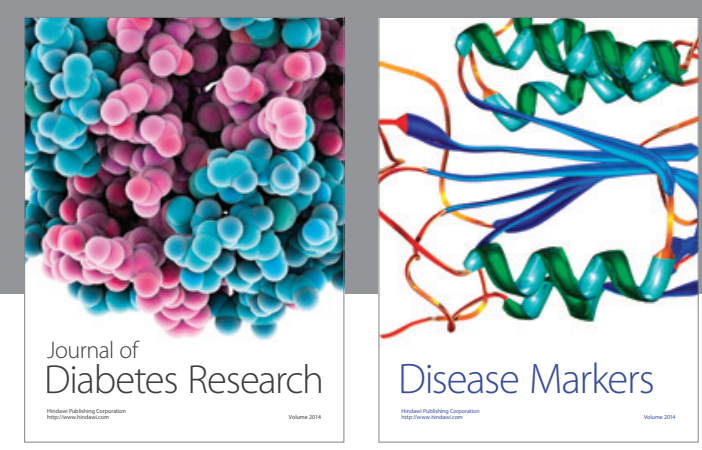

Disease Markers
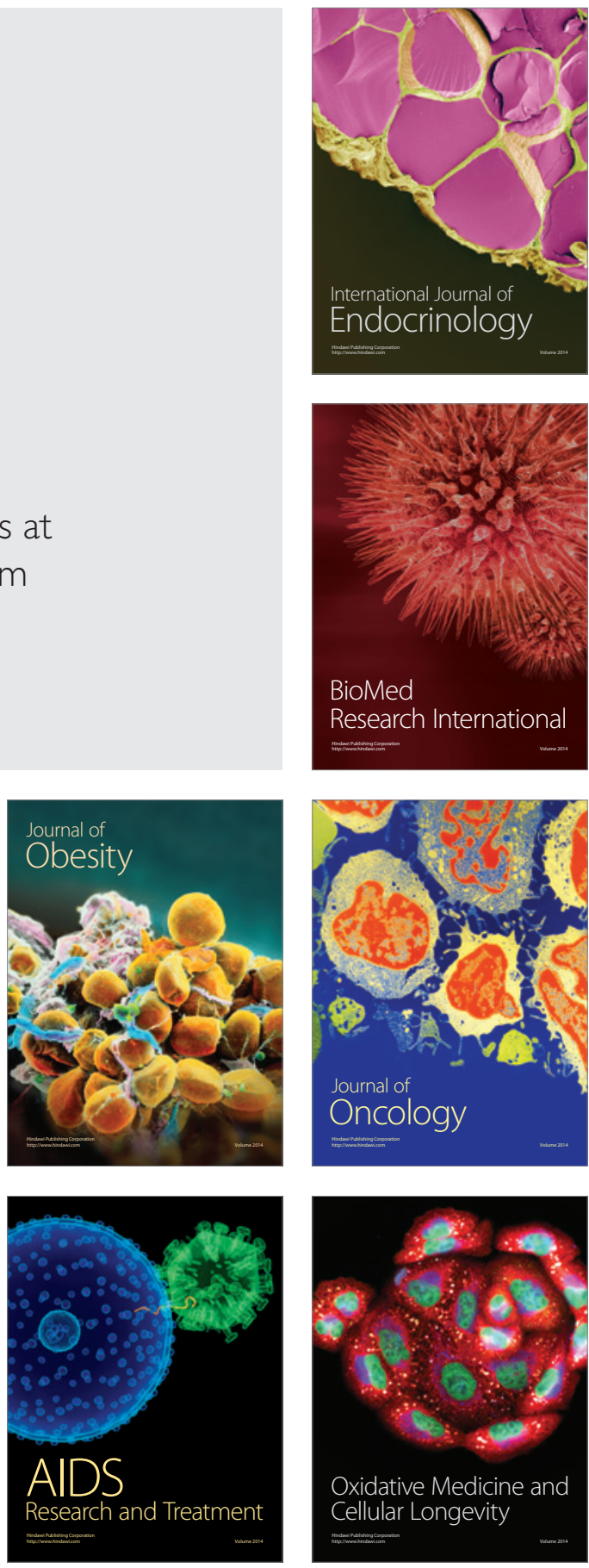